Zabytkoznawstwo i Konserwatorstwo XXXVIII, Toruń 2010

Elżbieta Szmit-Naud

Uniwersytet Mikołaja Kopernika w Toruniu

\title{
Iluzjonistyczne scenografie teatralne jako gatunek malarstwa dekoracyjnego Technika wykonania na przykładzie dekoracji francuskich teatrów dworskich
}

\section{Wprowadzenie}

Tluzjonistyczne dekoracje teatralne pojawiły się jako rezultat rozwoju wido1 wiska teatralnego i jego sceny i zyskały swój charakterystyczny kształt, wyznaczony przez scene pudełkową, już w XVII wieku. W postaci podlegającej niewielkim zmianom przetrwały do wielkiej reformy teatru, która nastąpiła w Europie u schyłku XIX i w pierwszych dekadach XX wieku i dała początek nowym formom teatralnej wypowiedzi oraz jej inscenizacyjnej oprawy. Klasyczne rozumienie zasad iluzji, a zarazem dekoracji teatralnej, oparło się temu nurtowi w teatrze mieszczańskim, stąd też dekoracje budowane zgodnie z tradycyjnymi normami mogły powstawać także w XX wieku. Z tego czasu pochodzą ostatnie opracowania objaśniające techniczne zasady ich tworzenia.

Zarys, nawet skrótowy, zagadnień związanych z historią teatru i jego przeobrażeniami wykracza szeroko poza ramy niniejszego artykułu. Zostaną tu one przywołane jedynie w zakresie niezbędnym dla właściwego usytuowania swoistego malarstwa dekoracyjnego, jakim są repertuarowe dekoracje teatralne. 
Ich funkcja, rozmieszczenie w przestrzeni scenicznej, metody montażu i manipulowania nimi w sposób oczywisty uwarunkowały technikę ich wykonywania i dobór materiałów, który zostanie tu przedstawiony na podstawie danych dotyczących XVIII- i XIX-wiecznych francuskich dekoracji scenicznych. Jednocześnie budowa tych obiektów determinuje ich trwałość i w znacznym stopniu zdolność przetrwania ${ }^{1}$.

\section{Powstanie dekoracji sceny pudełkowej, jej typologia i ewolucja}

Podwalin nowożytnej scenografii możemy poszukiwać u Witruwiusza. Jego traktat $\mathrm{O}$ architekturze, wydany w 1486 roku, pozwolił poznać urządzenie starożytnego teatru jak i zasady działania mechanizmów służących obsłudze malowanych dekoracji wymiennych, tzw. periaktów. Konwencja wiązała typ scenerii, która na nich figurowała, z rodzajem przedstawienia komedii, tragedii czy dramatu satyrycznego. Stąd też można wywieść trzy rodzaje perspektywicznych dekoracji zaproponowane przez Sebastiana Serlia (1475-1554), które stały się podstawą funkcjonujących do wielkiej reformy teatru dekoracji repertuarowych: monumentalnych dla tragedii, miejskich dla komedii i rustykalnych dla satyry. Serlio w 1618 roku oddzielił scenę od widowni ramą portalową zakrywającą niewykorzystywane $\mathrm{w}$ danym momencie elementy dekoracji i urządzenia służące tworzeniu scenicznej iluzji. Od tego czasu zasadnicze cześci sceny à l'italienne, czyli pudełkowej, są już ukształtowane. Giovanni Battista Aleotti w Teatro Farnese (1618/1619) jako pierwszy zastosował system kulis (od fr. coulisse - rowek, prowadnica, w której były przesuwane elementy dekoracji), wyposażył w maszynerię, która przez ponad dwa następne stulecia była niezbednym elementem scen

1 Zagadnienie podjęte w: E. Szmit-Naud, Préservation des décors historiques de théâtre: un défi pour la conservation préventive, Exemple du théâtre de la Reine à Versailles, Université Paris I, Paris 2005/2006 (praca master de Conservation préventive). W przygotowaniu opracowanie obejmujące całokształt problematyki związanej z zachowanym wyposażeniem scen historycznych teatrów w Europie, w tym kwestie działań służących przechowaniu i udostępnieniu tego dziedzictwa potomności. 
pudełkowych umożliwiających wystawianie oper i sztuk teatralnych, pozwalających na tzw. zmiany otwarte dekoracji (fr. changement à vue - zmiana na oczach widza) i szereg „nadnaturalnych” efektów specjalnych, nieodzownych w widowiskach epoki baroku i w XIX wieku w czasach romantyzmu.

Kolejni twórcy, którzy przyczynili się do rozwoju i rozkwitu sceny à l'italienne $\mathrm{w}$ wieku XVIII, byli zarazem architektami, inżynierami maszynistami i dekoratorami ${ }^{2}$. Pośród najbardziej znamienitych byli: Nicola Sabattini (1574-1654), autor podręcznika wykonania dekoracji i maszynerii ${ }^{3}$; Giacomo Torelli (1608-1678), który doprowadził do perfekcji zmiany otwarte zapoczątkowane przez Aleottiego i przyczynił się wydatnie do rozpowszechnienia się upodobania do „sztuk z maszynerią” we Francji i za jej pośrednictwem - w Europie ${ }^{4}$ Andrea Pozzo (1642-1709), mistrz malarstwa iluzjonistycznego, tworzący doskonałą sceniczną iluzję optyczną przestrzeni ; rodzina Galii da Bibiena, począwszy od Ferdinanda (1657-1743), autora nowej wizji scenicznej dekoracji dzięki zamianie perspektywy centralnej na diagonalną i kątową, kończąc na Antoniu (1700-1774); oraz Jean Jérôme Servandoni (1695-1766), również, podobnie jak Ferdinando, wprowadzający perspektywę ukośną. W Polsce pierwsza scena pudełkowa z kulisowymi dekoracjami, wzmiankowana dopiero w 1699 roku, została zbudowana dla Fryderyka Augusta Sasa przez Georga Christiana Fritschego na zamku warszawskim ${ }^{6}$. Sprawnym budowniczym teatralnym i zarazem maszynistą i dekoratorem był Szymon Bogumił Zug (1733-1807)7, znanymi, choć

2 „Maszynista” (od niem. Maschinist, fr. machiniste) - specjalista obsługujący maszynerię teatralną, a zwłaszcza zajmujący się ustawieniem dekoracji, za: K. Nadurska, Z polskiego słownictwa teatralnego, „Język Polski”, 1972, nr 52, s. 18-28; „dekorator” (od fr. décorateur) twórca koncepcji dekoracji, całościowego wyglądu sceny (w dzisiejszym rozumieniu scenograf), nadzorujący jej wykonanie, lub też malarz je wykonujący; nierzadko łączył te dwie funkcje (lub przynajmniej umiejętności).

3 N. Sabattini, Pratique pour fabriquer scènes et machines de théâtre, [Ravenna 1638], Neuchâtel 1994 (wyd. 1 - 1942).

4 Rozkwitły zwłaszcza w XVIII w. dzięki oddziaływaniu dworu francuskiego.

5 W traktacie Perspectiva pictorum et architectorum.

6 B. Król-Kaczorowska, Teatr dawnej Polski, budynki, dekoracje, kostiumy, Warszawa 1971, s. 118.

7 Ibidem, s. 120. 
niejedynymi malarzami dekoratorami tego czasu byli Antoni Smuglewicz i Jan Bogumił Plersch.

W epoce romantyzmu intensywnie odżyło zapotrzebowanie na nagłe zmiany dekoracji i „efekty specjalne” możliwe dzięki rozwiniętej w baroku maszynerii ${ }^{8}$. Do wybitnych dekoratorów tych czasów we Francji należeli: Ignace Degotti, Jean-Baptiste Isabey, Pierre-Luc Charles Ciceri, autor m.in. dekoracji słynnego baletu romantycznego Robert Diabet, a w Polsce - Antoni Sacchetti, Józef Hilary Głowacki, Stanisław Maksymilian Jasieński, Jan Spiziar ${ }^{9}$.

Zmiany w podejściu do koncepcji samej dekoracji malarskiej, od umowności do naturalizmu, nie wpłynęły, jak się wydaje, w sposób zasadniczy na ich materialną postać. Zarówno rodzaj elementów, kształtujących iluzjonistyczną scenografię, sposób ich wytwarzania, jak i zestaw środków do tego używanych nie podlegały istotnym modyfikacjom.

\section{Elementy kształtujące malarską dekorację sceny pudełkowej i stawiane im wymagania}

Określenie scenografia lub dekoracja sceny pudełkowej obejmuje „wszystko, co jest fermem, kulisa, kurtyna, płótnem zwisającym lub rozpiętym, wszystko, co ma powierzchnię malowaną" ${ }^{10}$.

Typowe malarskie dekoracje iluzjonistyczne były budowane z kilku, najczęściej pięciu do siedmiu, planów z prospektem, a w drugiej połowie XIX

8 Pośrednio zainteresowanie nimi dokumentują, wydane nieco później, opracowania: M. J. Moynet, L'envers du théâtre, machines et décorations, Paris 1873; G. Moynet, La machinerie théâtrale: trucs et décors: explication raisonnée de tous les moyens employés pour produire les illusions théâtrales, Paris 1893.

9 Zebrane informacje o działających na terenie Polski dekoratorach sceny włoskiej zawiera opracowanie: B. Król-Kaczorowska, op. cit., s. 117-165.

10 Według A. Pougin, Le dictionnaire historique et pittoresque du théâtre et des arts qui s'y rattachent, 1885. W języku francuskim opisywane elementy objęte są terminem décor, w odróżnieniu od décoration, który w teatralnym rozumieniu obejmuje także meble i akcesoria za: G. Fontaine, Le décor de l'opéra, un rêve éveillé, Paris 1996, s. 117. W jezzku polskim określenia scenografia i dekoracja bywają stosowane wymiennie, brak różnicującego odpowiednika. 
wieku z horyzontem w ostatnim planie, odseparowanych od widowni portalem sceny, kurtyną i płaszczem Arlekina, a później, już w XIX wieku, także dodatkową kurtyną, służącą ukryciu zmiany dekoracji w trakcie przedstawienia. Każdy z planów budowały elementy sztywne, dla których konstrukcję nośną stanowiły krosna, przemieszczane na scenie lub wysuwane na nią z podscenia albo spuszczane z nadscenia, oraz elementy wiotkie, zwieszane $\mathrm{z}$ nadscenia, inaczej sznurowni.

Sztywnym ruchomym elementem dekoracji były draperie Arlekina (czyli boki płaszcza, szal) pozwalające na regulację wielkości portalu sceny, pary przesuwanych lub przestawianych kulis w każdym planie (il. 1), jak i dużo większe elementy, tzw. fermy (fr. ferme, od fermer - zamykać), czyli dekoracje na krosnach ustawione równolegle do portalu sceny ${ }^{11}$; mogły być wyposażone w różnego rodzaju otwory - okna, drzwi, stawiane wtedy na środku sceny ${ }^{12}$; zwane są też zastawkami i w drugiej połowie XIX wieku określane jako „część dekoracji przed samym horyzontem, najcześciej przedstawiające góry, służące do zakrycia styku horyzontu z podłogą ${ }^{13}$. Później, w XIX wieku, kulisy w niektórych rodzajach dekoracji zastapiono malowanymi ścianami tworzącymi wraz z tylnym fermem „pokój sceniczny”, typ dekoracji używany do dziś. Mniejsze wolno stojące elementy nazywane czasem przystawkami, w kształcie np. pagórków, kęp, krzaków, drzew itp., dopełniaty dekorację. Wśród nich praktykable, czyli elementy o charakterze użytkowym, takie jak schodki, ławki itp., były jedynymi częściami nietraktowanymi iluzjonistycznie.

Elementy wiotkie to, poczynając od portalu sceny, lambrekin, kurtyna główna, później także antraktowa ${ }^{14}$, płaszcz Arlekina, sufity (sofity) dopełniające kulisy poszczególnych planów, mogące przedstawiać zarówno części budynków, wnętrz, niebo, jak i listowie (zwane też fartuchami), czasem kulisy

11 T. G. Boucher, Le petit théâtre du château de Compiègne, du jeu de paume Henri IV au théâtre Louis-Philippe, Bonneton-Paris 2000, s. 109.

12 G. Fontaine, op. cit., s. 275.

13 K. Nadurska, op. cit., s. 21.

14 Kurtyny teatralne $\mathrm{z}$ punktu widzenia problematyki konserwatorskiej opisała: M. Gursztyn, Malowane kurtyny teatralne, ich stan zachowania, przyczyny zniszczeń i wytyczne prac konserwatorskich, Torun 2007, praca magisterska napisana pod kier. dr. hab. Dariusza Markowskiego, maszynopis. 
zwieszone, inaczej zasłony (fr. pendrillons), principale będące połączeniem kulis z sufitem, prospekty czy horyzonty.

Wszystkie elementy dekoracji, by mogły być użyte w przestrzeni scenicznej, musiały spełniać kilka warunków. Mimo dużego formatu musiały być lekkie, aby można było je sprawnie i szybko przemieszczać ze sznurowni i podscenia z użyciem maszynerii i łatwo manipulować nimi na scenie podczas ustawiania oraz łatwo składować. Technika wykonania samych malowideł musiała zapewniać odpowiedni wygląd powierzchni, niepowodujący nieprzyjemnych refleksów światła, i zarazem pozwalać na jednorodne opracowanie dużych obszarów (np. prospektów, kurtyn), czyli umożliwiać szybkie działanie. Jednocześnie, zważywszy na sposób użytkowania i powierzchnię dekoracji, ich produkcja nie mogła pociaggá za sobą wygórowanych kosztów. Oczekiwania te bezpośrednio uwarunkowały technikę wykonania iluzjonistycznych dekoracji scenicznych i rodzaj stosowanych materiałów.

\section{Produkcja dekoracji}

W przypadku XVIII-wiecznych francuskich teatrów dworskich koncepcja dekoracji i wykonaniem szkiców zajmowali się rysownicy królewscy (de la Chambre et du Cabinet du roi) lub tytularni dekoratorzy Królewskiej Akademii Muzyki. Ich projekty były realizowane w pracowniach Menus-Plaisirs pod nadzorem osób pełniących funkcje „odpowiedzialnego za prace malarskie” ${ }^{15}$. W przypadku zorganizowanych pracowni, jak właśnie w Menus-Plaisirs, czy też pracowni dużych teatrów, jak Opera Paryska, Odeon czy Comédie-Française, samymi pracami nad dekoracjami kierował główny maszynista, stolarze trudnili się konstrukcjami, połączenia wykonywali ślusarze, tapicerzy

15 N. Vayssaire, La fabrication des décors (1760-1789), [w:] Victor Louis et le théâtre: scénographie, mise en scène et architecture théâtrale aux XVIII et XIX siècles: actes du colloque tenu les 8, 9 et 10 mai 1980 à Bordeaux à l'occasion du bicentenair de l'inauguration du Grand-Théâtre, Roudie, Paul and Rouyer, Philippe, Editors. Éditions du Centre national de la recherche scientifique (1982), s. 131; M.-H. Jordan, Décors et mises en scène d'un théâtre de la cour, [w:] Théâtre de la cour, les spectacles à Fontainebleau au XVIII siècle, Paris 2005, s. 74, 77. 
przygotowywali płócienne podłoża, a malarze przenosili na nie koncepcje rysowników czy dekoratorów ${ }^{16}$.

Od lat 20. XIX wieku oprawa romantycznych spektakli wymagała coraz liczniejszych i bardziej skomplikowanych scenografii, uwaga maszynistów musiała więc skupić się na ich obsłudze i wykonanie dekoracji zaczęto zlecać na zewnątrz. Stopniowo odpowiedzialność za nie przejmował artysta malarz dekorator, będacy jednocześnie autorem koncepcji i tworzący je we własnej malarni. We Francji praktykę te zapoczątkował P.-L. C. Ciceri, dekorator Opery, później także pełniący tę funkcję dla Comédie-Française, a po założeniu własnej pracowni dekorator wielu teatrów paryskich, a także dworskich. W tym też okresie produkcja dekoracji stała się nieco bardziej skomplikowana. Od pierwszej ćwierci XIX wieku, kiedy same dekoracje i ich usytuowanie na scenie były traktowane bardziej realistycznie, zmaterializowanie naszkicowanej koncepcji wymagało pośrednictwa makiety, początkowo rozumianej jako seria płaskich obrazów definiujących poszczególne plany, w drugiej połowie XIX wieku jako trójwymiarowy model. W malarniach przyteatralnych dekoratorzy sami je wykonywali, a w pracowni wspomnianego Ciceriego on sam tworzył szkice, które jego asystenci przetwarzali na barwne makiety.

Nie zawsze wykonanie scenicznych dekoracji iluzjonistycznych było przedsięwzięciem, w które angażował się cały zespół fachowców, podział ról i kompetencji niekoniecznie był tak wyraźny, na co wpływały i skala projektu, i zaplecze, jakim dysponowano. Wiemy na przykład, że w XVIII wieku w Polsce dwór saski zatrudniał po prostu "malarzy teatralnych”, ale pod koniec panowania Augusta III staraniem nadwornego budowniczego teatralnego i zarazem malarza dekoratora Szymona Bogumiła Zuga powstała malarnia przy Operalni. Kolejne teatry - królewskie z czasów Stanisława Augusta, publiczne i niektóre prywatne - miały swoje malarnie, czasem malarnie obsługiwały kilka teatrów, a zatrudniały dekoratorów i malarzy lub też artystów rzemieślników wykonujących niemal wszystkie prace samodzielnie ${ }^{17}$. Sam proces tworzenia dekoracji normalizowały jasno określone zasady.

16 D. Lauvernier, Le Temple de Minerve: un décor de scène du fonds des Menus Plaisirs datant de 1754, „Le bulletin de la Société De l'Histoire de l'Art Français”, 1992, s. 133; B. Daniels, J. Razgonnikoff, Le décor de téâtre à l'époque romantique, Paris 2003, s. 42, 43.

17 B. Król-Kaczorowska, op. cit., s. 120, 121, 123-158. 


\section{Etapy wykonania dekoracji i stosowane materiały}

Publikacje dostarczające informacji technicznych na temat wykonania scenicznych dekoracji iluzjonistycznych są nieliczne. Z wieku XVIII, z dzieła Watina $^{18}$, pochodzi opis malowania „płócien do dekoracji”, także teatralnych. Dokumenty archiwalne w postaci not wydatków, dzienników prac pośrednio informują o stosowanych materiałach i sposobie wykonania ${ }^{19}$. Uzupełniają je już XIX- i XX-wieczne opracowania o charakterze poradników opisujące tradycyjnie stosowane techniki ${ }^{20}$. Określenie materiałów budujących dekoracje i rzadkie informacje o przeprowadzonych analizach zawierają nieliczne publikacje omawiajace prace konserwatorskie wykonane przy dawnych dekoracjach $^{21}$. Własne obserwacje zachowanych XVIII- i XIX-wiecznych elementów francuskich dekoracji scenicznych, przeprowadzone in situ ${ }^{22} \mathrm{w}$ konfrontacji

18 J. F. Watin, L'art du peintre, doreur, vernisseur: Ouvrage utile aux artistes et aux amateurs qui veulent entreprendre de peindre, dorer et vernir toutes sortes de sujets en bâtiments, meubles, bijoux, équipages, etc., Paris 1977, s. 114, 115.

19 Ibidem, s. 129 - „nota ekspensy” Plerscha; dokumenty archiwalne pracowni francuskiej Królewskiej Akademii Muzyki oraz Menus-Plaisirs cytowane przez N. Vayssaire i D. Lauvernier, zachowane w archiwach narodowych, patrz przyp. 15, 16.

20 G. Moynet, La machinerie; X. de Courville, Décors de théâtre: invention, construction, peinture, conseils d'un artisan aux amateurs, Paris 1949; A. Boll, La décoration théâtrale: conseils aux amateurs, Paris 1957; G. Coquiot, Nouveau manuel de peintre décorateur de théâtre, Paris 1927 (faksymil z 1980 r.); V. Polutin, The continental method of scene painting, London 1980 (wyd. 1 - 1927).

21 V. Trémoulet, L'intervention de sauvetage d'une partie du fonds des décours de scène $d u$ petit théâtre Louis-Philippe du château de Compiègne, [w:] Arts du spectacle: collections patrimoniales et documentation, XXIII Congrès International, Société Internationale des Bibliothèques et des Musées des Arts du Spectacle, Paris, 25-30 Septembre 2000, BNF, Paris 2002, s. 115-122; idem, Conservation et restauration des décors, [w:] Théâtre de Cour: Les spectacles à Fontainebleau au XVIII siècle, réd. V. Droguet, M.-H. Jordan, Paris 2005, s. 85-89; J. Ortner, Die Bühnenbilder des Barocktheaters Stift: Lambach in Oberösterreich, Untersuchung, exemplarische Konservierung und Restaurierung, "Zeitschrift für Kunsttechnologie und Konservierung”, 1999, Bd. 13, Nr. 2, s. 305-316.

22 W teatrze Marii Antoniny w Trianon w Wersalu (in. Petit Teâtre de la Reine), „małym teatrze" Ludwika Filipa w Compiègne, teatrze Napoleona III w Fontainebleau oraz dekoracji pochodzących z teatru Ludwika Filipa w Eu. 
z danymi pochodzącymi z literatury, jak i obserwacja pracy ekipy dekoratorów wykonujących kopię XVIII-wiecznej dekoracji ${ }^{23}$ stanowią podstawy prezentowanego niżej opisu techniki wykonania dekoracji sceny à l'italienne.

\section{Wykonanie konstrukcji nośnej}

Krosna kulis, fermów, zastawek, przystawek budowano z ramiaków wyciętych z drewna iglastego ${ }^{24}$. Dla uzyskania form bardziej skomplikowanych, obłych czy o rozbudowanej krzywej linii, np. listowia (fr. silhouettes), do krosien stanowiących zasadniczy zrąb danego elementu dekoracji przybijano deski z drewna liściastego, a w późniejszym okresie sklejki, które już po namalowaniu dekoracji odpowiednio wycinano (il. 2). Ramiaki stosowane do budowy krosien mogły mieć różną długość - od 1,5 $\mathrm{m}^{25}$ do około $2,7 \mathrm{~m}^{26}$, w przekroju miały 2,2-2,7 cm lub 3,4 cm grubości, $5-7,5 \mathrm{~cm}^{27}$, czasem $10 \mathrm{~cm}$ szerokości ${ }^{28}$. Wysokość kulis czy ferm przekraczała nierzadko kilkakrotnie długość ramiaków - nawet w mniejszych teatrach miały one ponad 5 metrów - stąd też, by uzyskać pionowe listwy krosien, łączono ramiaki ze sobą, ścinając końce ukośnie i wzmacniając spoinę klejową gwoździami (il. 2). Listwy poprzeczne krosien, o tym samym przekroju co pionowe, miały zróżnicowaną długość, zależnie od potrzeb, na ogół nie większą niż 1,5 m. Listew nie fazowano. Krosna kulis wzmacniano poprzeczkami, przy czym pierwsza od dołu, czyli „dłon”" (fr. paume), standardowo znajdowała się na wysokości $70 \mathrm{~cm}$ i stanowiła uchwyt pomagający maszynistom przy przenoszeniu dekoracji. Połączenia listew wykonywano najcześciej na nakładke prosta, choć możliwe były także połączenia stykowe, czopowe, na nakładkę ściętą, wczepowe. Wczepowo montowano ukośne wzmocnienia z listewek w narożnikach.

23 W Opèra Royal w Wersalu.

24 N. Vayssaire, op. cit., s. 134, wymienia świerk.

25 X. de Courville, op. cit., s. 43.

26 N. Vayssaire, op. cit., s. 134.

27 W przypadku XIX-wiecznych dekoracji repertuarowych wykonanych przez Ciceriego na zamówienie króla Ludwika Filipa do teatru Marii Antoniny w Wersalu; pomiar na miejscu.

28 W przypadku XIX-wiecznych dekoracji wykonanych przez Ciceriego w teatrze Ludwika Filipa w Compiègne, pomiar na miejscu. 
Narożniki wzmacniano również trójkątami ze sklejki. Otrzymywano, mimo dużych rozmiarów, lekką konstrukcję. Kulisy wymagały czasem tzw. krosien łamanych - łączono wówczas krosna ze sobą za pomocą prostych zawiasów kutych (il. 3). Tym samym sposobem wmontowywano np. drzwi czy okna, wbudowując krosno w krosno. Fermy powstawały z łączenia wielu krosien, tak by utworzyć z nich ścianke. Nie zawsze sczepiano je zawiasami na stałe, czessto stosowano połączenie demontowalne, używając do tego zawiasów z kołkiem, zawleczką lub haków mocowanych na pionowych listwach, pomiędzy którymi przewlekano sznur (il. 4). Sznurami przytwierdzano także kulisy do masztów przyczepionych do wózków w podsceniu, które umożliwiały ich przemieszczanie w prowadnicach.

W przypadku wiotkich elementów dekoracji, czyli kurtyn, prospektów, fartuchów i sufitów, elementami konstrukcyjnymi służącymi do ich zawieszenia były łata lub sztanga, czasem w formie draga o przekroju okrąłym. Jego średnica mogła wynosić od 3,8 do $5 \mathrm{~cm}^{29}$. Mógł być wykonany z różnego drewna, np. jesionu ${ }^{30}$ lub świerku ${ }^{31}$. Do obciążania prospektów, by zwisały odpowiednio naprężone, używano podobnego draga mocowanego w dolnej części (opis poniżej).

\section{Przygotowanie płóciennego podłoża dekoracji}

Płótno stosowane do dekoracji teatralnych powinno spełniać kilka wymogów: być gęste, aby farby nie przenikały na odwrocie, mocne i w przypadku malowideł zwieszanych - wiotkie, by można było je składać czy zwijać, nie mnąc zbytnio. W XVIII i XIX wieku najczęściej wykorzystywano płótna lniane, zdarzało się też zastosowanie płócien konopnych, co znajduje potwierdzenie w zachowanych dekoracjach ${ }^{32}$, przy czym nierzadko były one jednak grubo

29 Pomiar na miejscu, dekoracje XVIII- i XIX-wieczne w teatrze Marii Antoniny, gdzie największe płótna mierzą $6,7 \mathrm{~m} \times 9,3 \mathrm{~m}$, w przypadku płócien o wymiarach większych zastosowano dragi lub łaty o większym przekroju.

30 D. Lauvernier, op. cit., s. 134.

31 W teatrze Marii Antoniny - za: Rapport d activité de l'EPV, 2001, s. 85; A. Bataille, Lexique de la machinerie théâtrale, Paris 1989, s. 82.

32 D. Lauvernier, op. cit., s. 134; V. Trémoulet, L'intervention, s. 116; idem, Conservation, s. 85; G. Coquiot, op. cit., s. 131. 
tkane. W późniejszych czasach, w XX wieku, używano płócien bawełnianych i jutowych ${ }^{33}$.

Przygotowaniem podobrazi zajmowali się tapicerzy. Używano szerokich płócien, by, w przypadku dekoracji zwieszanych, zszywać bryty przede wszystkim poziomo, co miało zapewnić bardziej regularne naprężenie. W praktyce jednak często tworzono podobrazie prospektów i sufitów, zszywając płótna i poziomo, i pionowo, z wielu kawałków (il. 5), co czasem mogło być rezultatem ich wtórnego użycia.

Po zszyciu brytów płótna do odpowiednich wymiarów w jego górnej cześci szyto tunel pozwalający na wsunięcie belki służącej do podwieszenia w sznurowni po wycięciu otworów, przez które przewlekano sznur (il. 6). W przypadku dekoracji w głębi sceny, prospektów czy horyzontów szyto jeszcze dwa poziome tunele: jeden przeciętnie w połowie wysokości i drugi nad podłogą, ukryty za osłoną o szerokości około $20 \mathrm{~cm}$, która opierając się na podłodze, maskowała prześwity. W tunele wprowadzano później listwy (dragi), które pozwalały lepiej naprężyć płótno i, przy zmianie dekoracji, odpowiednio je podnieść do sznurowni i złożyć (il. 6).

Płótna na krosnach były mocowane od przodu za pomoca gwoździ tapicerskich (il. 3). Przybijano je również do desek formujących wspomniane wcześniej „sylwety”, jednocześnie przyklejając płótno.

Najprawdopodobniej jeszcze przed rozpięciem płócien na krosnach przyklejano na ich odwrocie papier ${ }^{34}$. Jego rodzaj nie był określony ścisłymi wskazaniami. Mógł być to np. papier z masy szmacianej lub drzewnej35. Przyklejano go klajstrem mącznym, czasem też klejem kazeinowym ${ }^{36}$. Osłony z papieru pełniły kilka funkcji - ułatwiały lepsze naprężenie podobrazia,

33 X. de Courville, op. cit., s. 35.

34 Obecność papieru stwierdzono także pod listwami krosien.

35 V. Trémoulet, Conservation, s. 86 - papier z masy szmacianej stwierdzono w analizach dekoracji z Fontainebleau. W innych przypadkach obserwacja skłaniała do przypuszczenia zastosowania papieru z włókna drzewnego - w dekoracjach z Compiègne, informacja od V. Trémoulet.

36 Klajster z mąki poleca w tym celu Watin - J. F. Watin, op. cit., s. 114, 115. Obecność tego spoiwa stwierdzono w przypadku dekoracji w Compiègne - V. Trémoulet, L'intervention, s. 116, w przypadku dekoracji z Fontainebleau analizy wykazały obecność kazeiny V. Trémoulet, Conservation, s. 86. 
usztywniały je i zarazem sprawiały, że dekoracje stawały się nieprzezroczyste, co było istotne, gdyż za nimi były mocowane lampy oświetlające poszczególne plany. Zdarzało się, że nie zaklejano odwrocia. Nie było takiej potrzeby, gdy wtórnie używano płócien stanowiących wcześniej inną dekorację.

Czasem w tzw. „transparentach”, czyli partiach dekoracji, w których wykorzystywano efekt prześwitywania (by imitować np. płomienie), pożądana była przezroczystość zastosowanego materiału. Wówczas używano tiulu, gazy lub też przesycano cienkie płótno olejem bądź woskiem ${ }^{37}$.

\section{Nanoszenie zaprawy}

Podobrazia przeznaczone na prospekty, principale, sufity czy kurtyny były rozpinane na drewnianej podłodze pracowni za pomoca gwoździ tapicerskich $^{38}$. Przeklejano je za pomocą kleju z wypełniaczem, rodzaju leszu, a na podobrazia rozpięte na krosnach po przeszlifowaniu kładziono drugą warstwę mająca już charakter zaprawy. Także i tę warstwę szlifowano ${ }^{39}$. Podobrazia wiotkie przeznaczone na zwieszane dekoracje mogły nie być zaprawiane. We Francji jako wypełniacz stosowano białe margle (blanc de Bougival ${ }^{40}$, blanc de Meudon), które dzięki zawartości glinek zapewniały większą elastyczność niż sama kreda. Spoiwem zaprawy były kleje glutynowe ${ }^{41}$.

\section{Przeniesienie rysunku}

Zarys kompozycji dekoracji z uprzednio przygotowanego rysunku bądź makiety przenosili szkicownicy (fr. traceur), posługując się siatką zaznaczoną na płóciennym podobraziu za pomocą sznurka natartego pyłem węglowym ${ }^{42}$,

37 G. Moynet, L'envers du théâtre, machines et décorations, Paris Hachette et Cie 1875, s. 119; Secrets concernant les arts, 1801, s. 51-52; V. Trémoulet, Conservation, s. 87.

38 X. de Courville, op. cit., s. 32.

39 J. F. Watin, op. cit., s. 115.

40 Ibidem.

41 Ibidem - colle de gant; N. Vayssaire, op. cit., s. 132 - colle de Gand czy de Flandre, na podstawie zapisków archiwalnych dotyczących wykonania dekoracji.

42 X. de Courville, op. cit., s. 52; A. Boll, op. cit., s. 74. 
utrwalając niezbędne linie tuszem ${ }^{43}$. Rysowano, używając linijki na tyczce (il. 7). W XVIII i XIX wieku kompozycję zaznaczano ołowianymi i czerwonymi rysikami, kredą lub, prawdopodobnie, tuszem ${ }^{44}$. Autorzy publikacji z XX wieku opisują szkicowanie kompozycji z użyciem węla osadzonego w trzymadle na tyczce ${ }^{45}$ (il. 7). Bardziej skomplikowane elementy kompozycji kopiowano za pomocą przepróchy, do powtarzalnych używano szablonu.

\section{Malowanie}

W XVIII i w pierwszej ćwierci XIX wieku malowanie prospektów, principali, sufitów i kurtyn odbywało się, po odpięciu z podłogi zagruntowanych płócien z przeniesionym rysunkiem, w pozycji pionowej, na specjalnie w tym celu budowanych rusztowaniach ${ }^{46}$. Później odstapiono od tej metody i malowano dekoracje na płasko, chodząc po nich.

Do malowania używano „tempery” (fr. detrempe), lecz termin ten oznaczał cześciej farby klejowe, a nie rzeczywiste emulsje. We Francji spoiwo stanowił klej glutynowy skórny różnych rodzajów, klajster mączny lub krochmal ${ }^{47}$. Do nanoszenia złotych blików polecano mordant otrzymywany z wosku, oleju lnianego i terpentyny weneckiej. Na podstawie not archiwalnych można wnioskować użycie samej terpentyny ${ }^{48}$.

43 N. Vayssaire, op. cit., s. 132.

44 Ibidem. Na jednym z prospektów XVIII-wiecznej dekoracji przechowywanej w teatrze Marii Antoniny w Wersalu zaobserwowano ślady rysunku czerwoną kredką, na innym prospekcie z XIX w. - ołówkiem.

45 X. de Courville, op. cit., s. 52; A. Boll, op. cit., s. 74.

46 D. Lauvernier, op. cit., s. 134 - świadczy o tym archiwalna nota z 1754 r.; G. Coquiot, op. cit., s. 117.

47 J. F. Watin, op. cit., s. 115, przez nazwe „tempera” rozumie klej skórny (ze skórek na rekawiczki, tzw. colle de gant), podobnie autorzy XX-wiecznych publikacji mówią o kleju skórnym: A. Boll, op. cit., s. 73; G. Coquiot, op. cit., s. 122; X. de Courville, op. cit., s. 53, 54. N. Vayssaire, op. cit., s. 132, na podstawie not archiwalnych cytuje pozostałe spoiwa; D. Lauvernier, op. cit., s. 134, potwierdza, również na podstawie zapisków, stosowanie klajstru mącznego.

48 J. F. Watin, op. cit., s. 116; N. Vayssaire, op. cit., s. 132. 
Farby przygotowywano oddzielnie, dodając klej do pasty pigmentowej uzyskanej z pigmentów rozrobionych z wodą. Paleta stosowanych barwników ulegała niewielkim zamianom. Informacje podane przez Watina, zapiski archiwalne i analizy kilku dzieł pozwalają stwierdzić, że w XVIII wieku mogły się na nią składać: biel, najprawdopodobniej kreda lub biały margiel, ten, którego używano w zaprawie, żółcień neapolitańska, żółty lak stil de grain, aurypigment, ziemne żółcienie, czerwienie i brązy (ugry, czerwienie i umbra), czerwień lakowa, cynober, minia, czerwień pruska (palony błękit pruski), malachit, błękit popiołowy (najprawdopodobniej z azurytu - odnotowywano jego wysoką cenę), błękit pruski, indygo, bistr, czerń kostna, czerń tzw. niemiecka oraz złoto i tzw. złoto niemieckie, czyli jasna miedź w płatkach (rozdrobnionych) ${ }^{49}$. Paleta stosowana w XIX i już w XX wieku była bogatsza o pigmenty chromowe i ich mieszaniny (jak np. „zieleń angielska” z błękitu pruskiego z żółcienią chromianową) oraz syntetyczne laki anilinowe ${ }^{50}$. Według informacji z tego czasu paleta wykorzystywana do malowania dekoracji teatralnych składała się z tych samych pigmentów co stosowane w malarstwie sztalugowym, lecz grubiej zmielonych, gorszej jakości i zawierających dodatki wypełniaczy w celu obniżenia kosztów ${ }^{51}$.

Malowanie wymagało asortymentu przystosowanych do tego narzędzi (il. 7). Do nanoszenia pierwszej warstwy farb służyły duże pęzle podobne do mioteł (francuska nazwa balai - miotła), które trzyma się oburącz; do malowania detali - pędzle okragłe różnej wielkości, czasem o zgrupowanych kiściach, z białej szczeciny, a do nanoszenia złotych blików - pędzle z włosia borsuczego, miotełki z tkaniny - wszystkie osadzone na tyczkach pozwalających na swobodną prace w pozycji stojącej. Paleta miała formę szerokiej skrzynki z cynkowym dnem (il. 8), farby przygotowywano w ceramicznych garnkach, a do ich przenoszenia podczas malowania służyło pudło z dwie-

49 J. F. Watin, op. cit., s. 115-117; N. Vayssaire, op. cit., s. 132, 133; B. Król-Kaczorowska, op. cit., s. 129; V. Trémoulet, Conservation, s. 86, 87.

50 A. Boll, op. cit., s. 73.

51 V. Polutin, op. cit., s. 17. Bardziej wyczerpujące informacje dotyczące techniki wykonania malarskich dekoracji w XIX, XX w. zostaną zamieszczone w publikacji wzmiankowanej w przyp. 1. 
ma pionowymi listwami po bokach połączonymi listwą poziomą stanowiącą uchwyt ${ }^{52}$.

Zalecano dobieranie barw przez wykonanie próbnika zestrojonego z kolorystyką makiety lub modelu ${ }^{53}$. Dobrane tony w większej ilości przygotowywano we wspomnianych garnkach. Pokrywano nimi najpierw większe połacie, później wmalowując detale i posługując się mieszaninami tworzonymi na palecie. Relief architektury czy rzeźb podkreślano złoceniami wykonywanymi na żółtym podmalowaniu, na które nanoszono szrafowaniem mordant, a następnie sproszkowane „złoto”, którego nadmiar po wyschnięciu omiatano.

Praca malarza dekoratora wymagała zdecydowania, dość szybkiego działania i umiejętności przewidywania zmiany barwy podczas schnięcia. Walor warstw malowanych farbami klejowymi mógł zmienić się bardzo wydatnie. Zasadą było różnicowanie stopnia sklejenia farb zależnie od tego, czy służyły do malowania sztywnych, czy wiotkich elementów dekoracji. Te ostatnie wykonywano farbami o mniejszym stężeniu spoiwa - ze względu na ryzyko łuszczenia się podczas składania lub zwijania.

Malowane na płótnie sufity czy fartuchy o rozbudowanej, koronkowej formie dolnej części, na przykład korony drzew, po wycięciu podklejano do odwrocia siatką tapicerską (il. 9). W XX wieku obecność siatki uznawano za charakterystyczną cechę dekoracji już „niemodnych” ${ }^{54}$.

W przypadku sztywnych elementów scenografii, które miały nieregularny kształt, np. listowia, dopiero po ukończeniu malowania domontowane do krosien deski stanowiące podłoże docinano piłą zgodnie z rysunkiem.

\section{Przemalowywanie i wtórne wykorzystywanie dekoracji}

Technika wykonania iluzjonistycznych dekoracji teatralnych była dobrze dostosowana do celów, w jakich ją tworzono - powstające malowidła były lekkie, warstwy malarskie uzyskane w technice klejowej czy temperowej ce-

\footnotetext{
52 G. Coquiot, op. cit., s. 117-121.

53 A. Boll, op. cit., s. 76.

54 X. de Courville, op. cit., s. 37.
} 
chowała świeża kolorystyka i ostrość detalu odpowiednie do tworzenia iluzji w przestrzeni sceny i w jej oświetleniu.

Zastosowane materiały i technika niosły jednak ograniczenia, z których dobrze zdawano sobie sprawe, przede wszystkim niewielką trwałość dekoracji. Ich efemeryczność była powszechnie akceptowana. Nie zakładano, że przetrwają one ponad trzydzieści lat, przy czym co dziesięć lat należało je odświeżać ${ }^{55}$. Pierwszych zniszczeń malowidła doznawały już podczas transportu z malarni do teatru, kolejne następowały podczas użytkowania i tradycyjnego składowania - okopcenia, zarysowania, zgniecenia, wykruszenia, nawet rozdarcia, a czasem, przy dłuższym składowaniu - zalania ${ }^{56}$. Powodami „odświeżania”, czyli reperacji i przemalowywania dekoracji, nie były wyłącznie zniszczenia powodowane użytkowaniem, lecz także dostosowywanie ich do aktualnych gustów czy ducha przedstawienia, w którym miały być wykorzystane. Pierwsza motywacja dotyczyła głównie wnętrz, tzw. salonów przemalowywanych, zwłaszcza w XIX wieku, zgodnie z panującą modą. Druga odnosiła się na przykład do monumentalnej architektury. Analiza zapisków archiwalnych dotyczących zachowanej dekoracji Światyni Minerwy, powstałej w malarni Luwru w 1754 roku, pozwala stwierdzić, że w ciaggu trzydziestu trzech lat odświeżano ją, przystosowywano i częściowo przemalowywano sześć razy.

Odświeżanie dekoracji mogło być jednoznaczne z cześciowym jej zmywaniem - stosowana do malowania „tempera” klejowa czy z klajstru mącznego pozwalała na taką praktyke.

Było rzeczą naturalną, że iluzjonistyczne dekoracje repertuarowe mają służyć aż do zużycia i gdy nie nadawały się już do bezpośredniego wykorzystania jako takie, niszczono je bądź odzyskiwano ich podobrazia, czyli płótno. Po zmyciu zniszczonej pierwotnej dekoracji mogło ono, po odpowiednim zszyciu kawałków, zostać wykorzystane w sufitach (patrz il. 5) albo posłużyć jako podobrazie elementów sztywnych, na krosnach, przy czym w tym wypadku

55 B. Daniels, J. Razgonnikoff, op. cit., s. 45.

56 E. Szmit-Naud, Dawne scenografie teatralne - czynniki decydujące o ich stanie zachowania i charakterystyka zniszczeń - artykuł złożony do druku. 
usuwanie starych nawarstwień nie było konieczne - nową dekorację czasem malowano po stronie odwrocia starej, a dawne warstwy malarskie stanowiły przy okazji usztywnienie podobrazia i wzmagały jego nieprzezroczystość.

Zachowane do dziś przykłady iluzjonistycznych scenografii są żywym dokumentem rzadkiej obecnie specjalności malarstwa dekoracyjnego i świadectwem ważnej epoki w dziejach teatru. Prócz wartości historycznej scenografie te mają niezaprzeczalne walory estetyczne i nierzadko artystyczne (il. 10). Jakość ich opracowania świadczy o mistrzowskim operowaniu iluzyjną przestrzenią sceny. Zarysowana w niniejszym tekście technika wykonania scenicznych dekoracji ukazuje kruchość materii będącej nośnikiem tej iluzji. Budowa dawnych dekoracji teatralnych i sposób postępowania z nimi warunkują ich trwałość i zarazem wskazuja, jak trudne jest zadanie zachowania tego unikalnego malarstwa dekoracyjnego, stanowiącego istotne dziedzictwo historii teatralnej scenografii. 


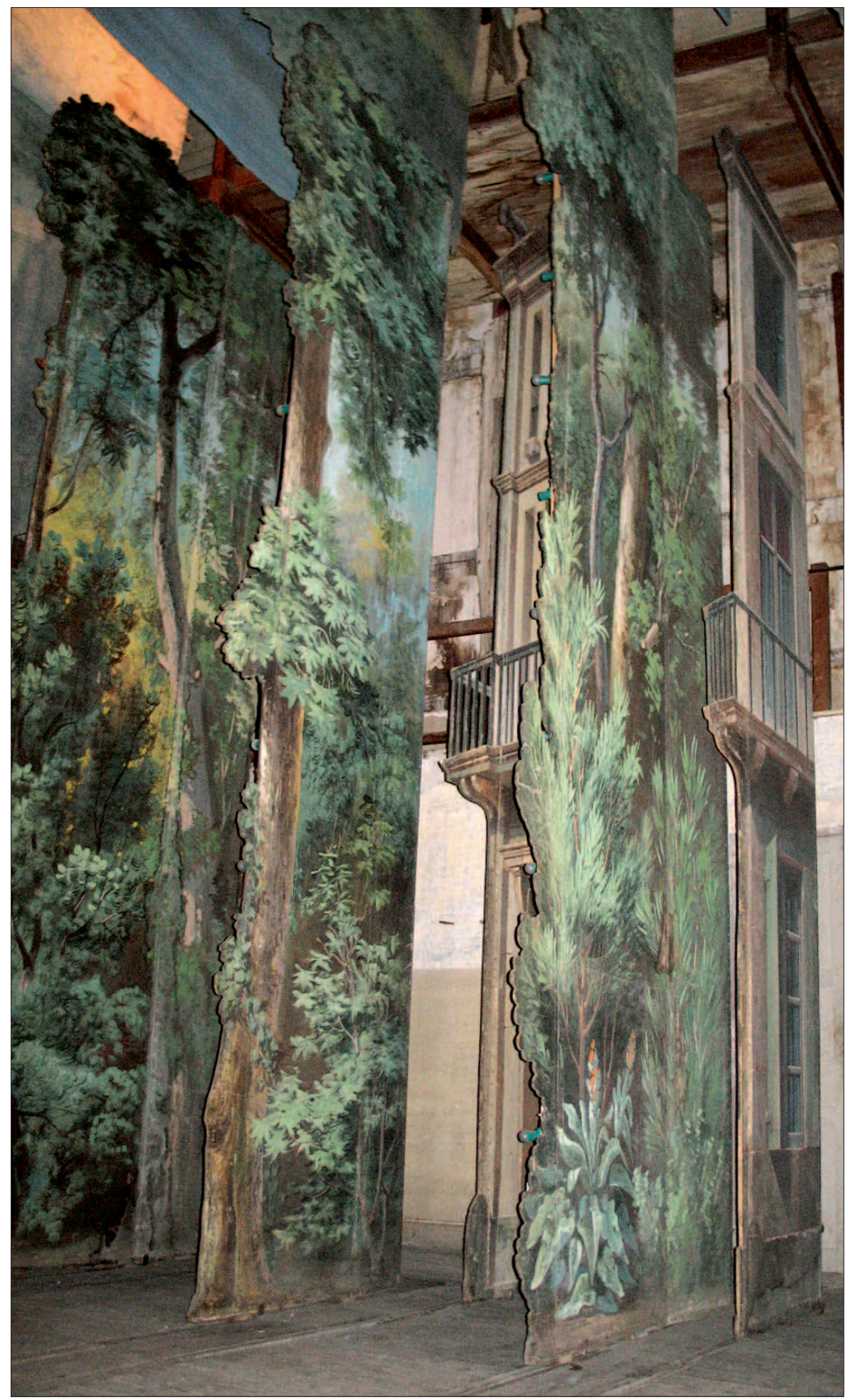

Il. 1. Kulisy iluzjonistycznych dekoracji: P.-L. C. Ciceri, 1836 r., Las i Plac miejski osadzone na scenie teatru dworskiego w Compiègne (fot. E. Szmit-Naud) 


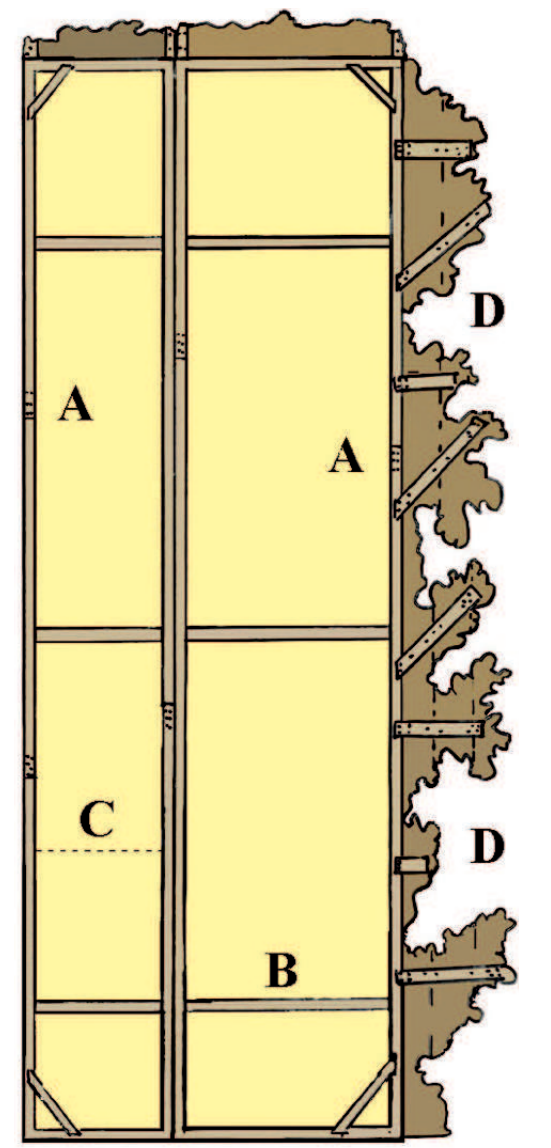

Il. 2. Schemat konstrukcji krosna kulis

o sylwetowym konturze: A - wzmocnienia

połączeń ramiaków gwoździami, B - poprzeczka

służąca do niesienia dekoracji, C - szew płótna,

D - sylwety (rys. E. Szmit-Naud)

Il. 3. Fragment kulis złożonych z dwu krosien połączonych trwale (fot. E. Szmit-Naud)

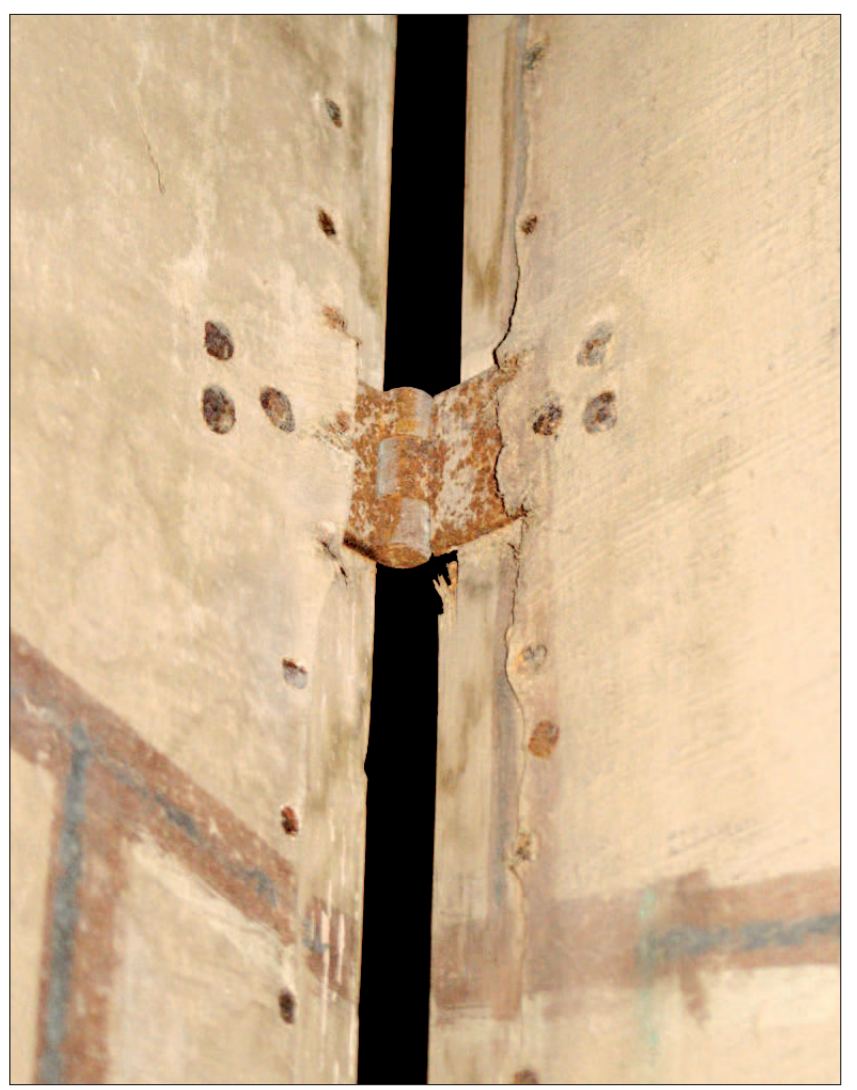


a)

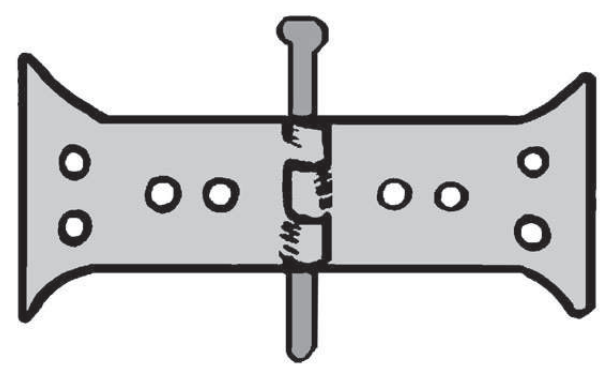

b)

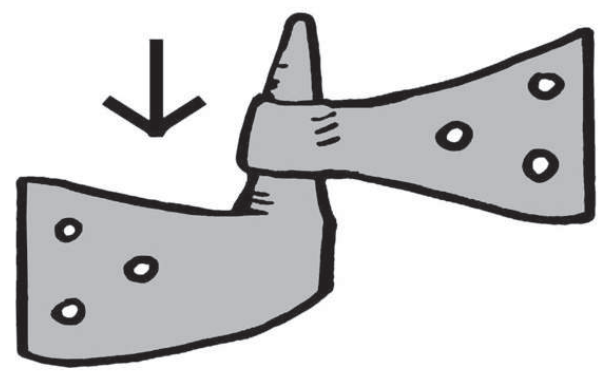

C)

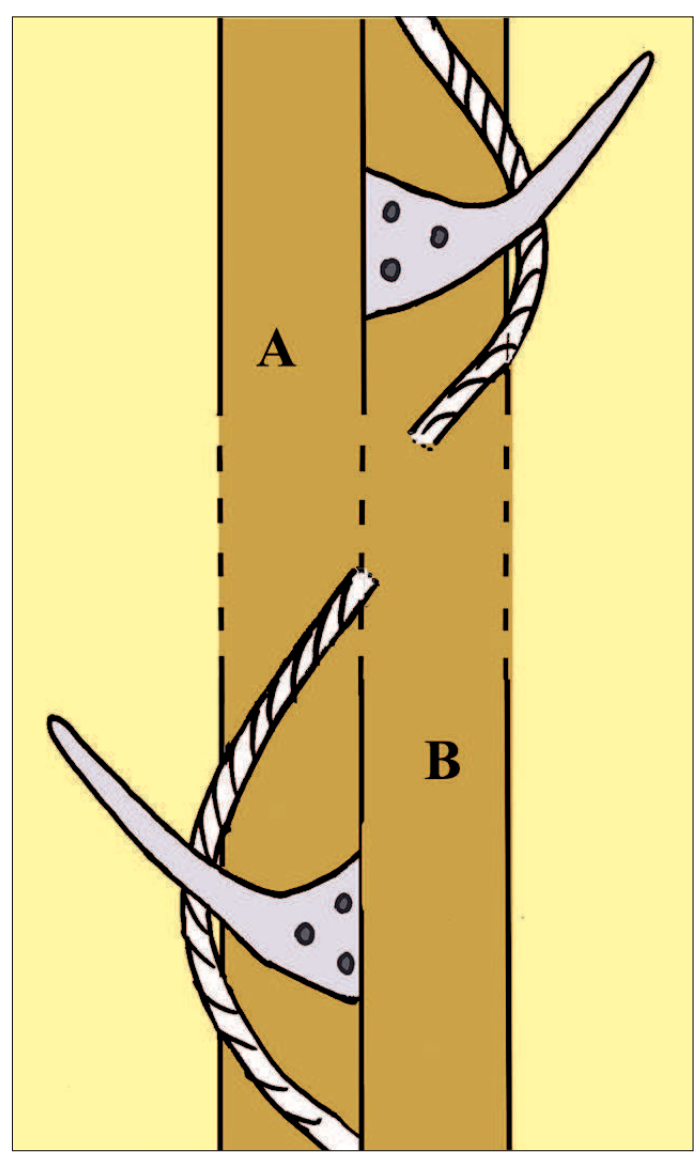

Il. 4. Demontowalne połączenia sztywnych elementów dekoracji scenicznej - przykłady; a) i b) zawiasy, c) system haków i sznur (rys. E. Szmit-Naud) 


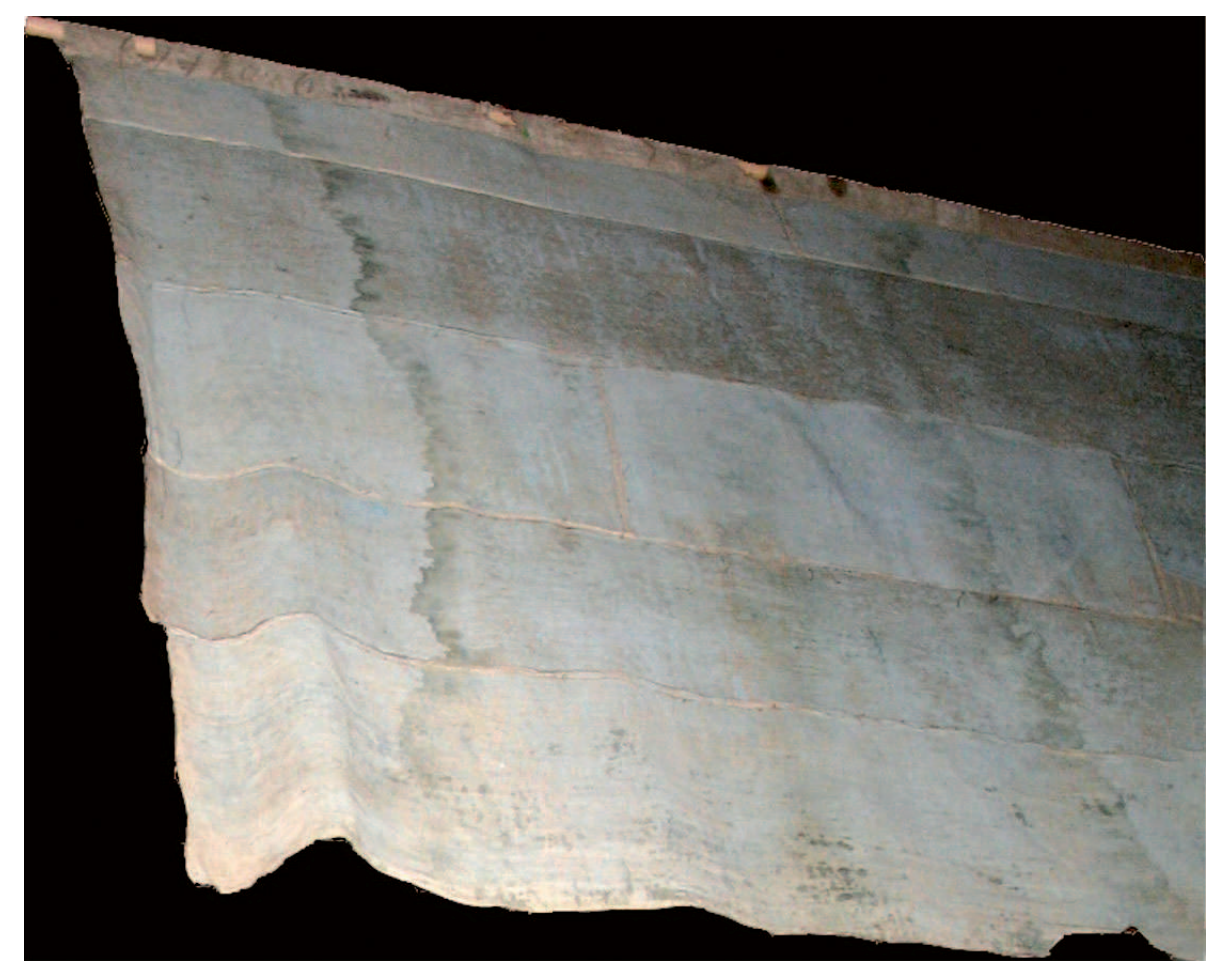

Il. 5. Przykład sufitu (odwrocie) (fot. E. Szmit-Naud)

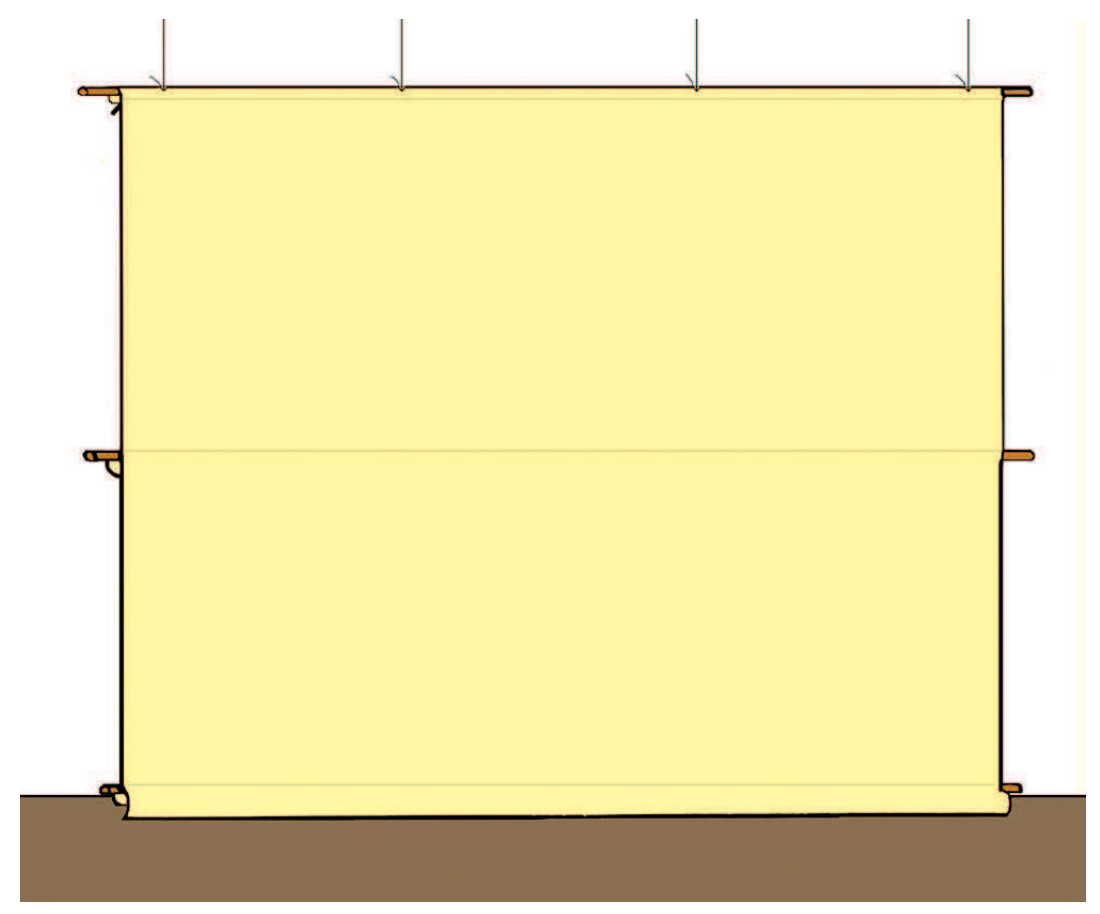

Il. 6. Schemat budowy prospektu (rys. E. Szmit-Naud) 


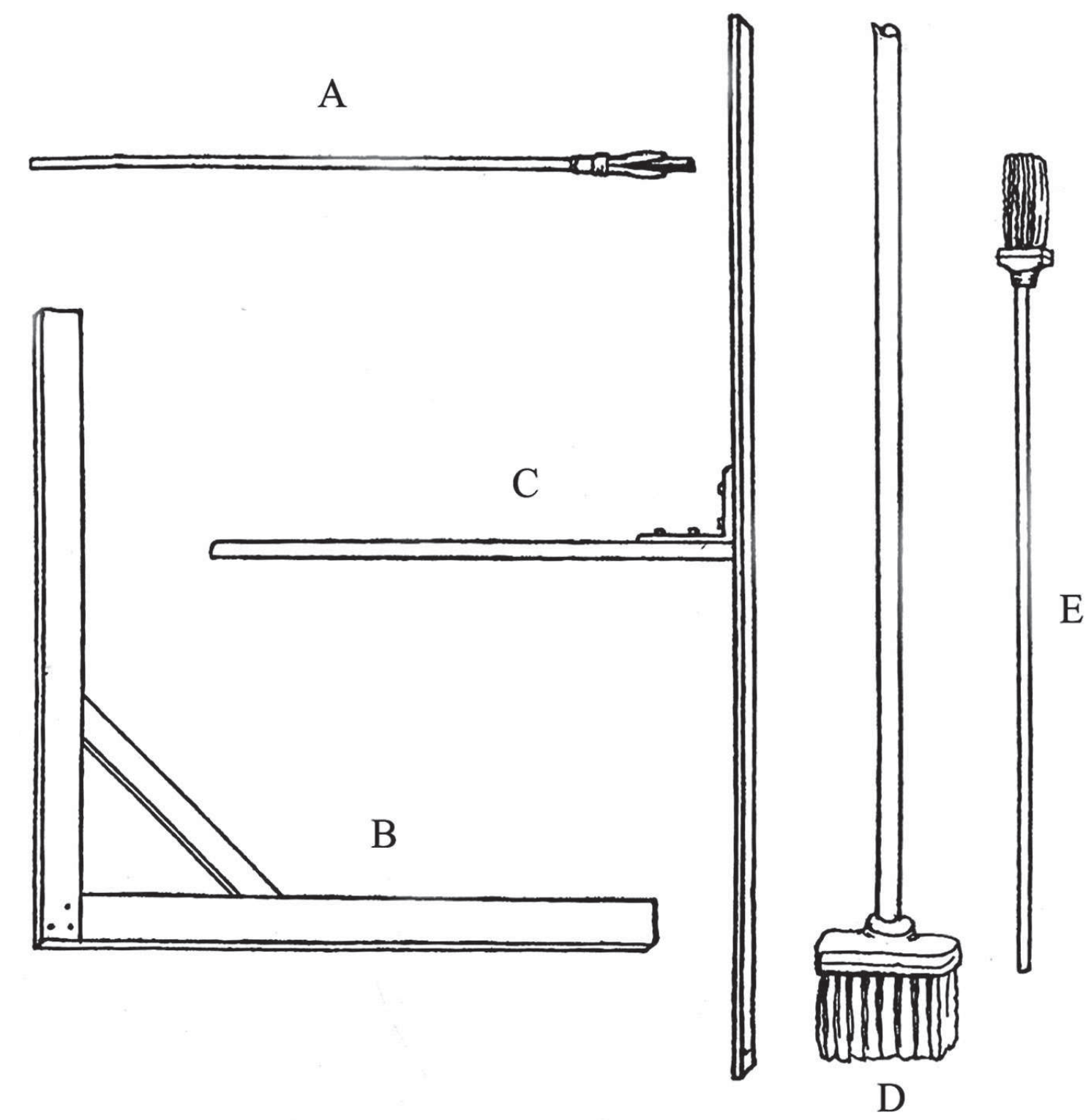

Il. 7. Typowe narzędzia malarza dekoratora: A - wegiel, B - kątownik, C - liniał, D - peedzel do malowania oburacz (typu „miotła”), E - peedzel do malowania detali (rys. E. Szmit-Naud na podstawie: V. Polutin, The continental method of scene painting, London 1980, s. 7, rys. 2) 


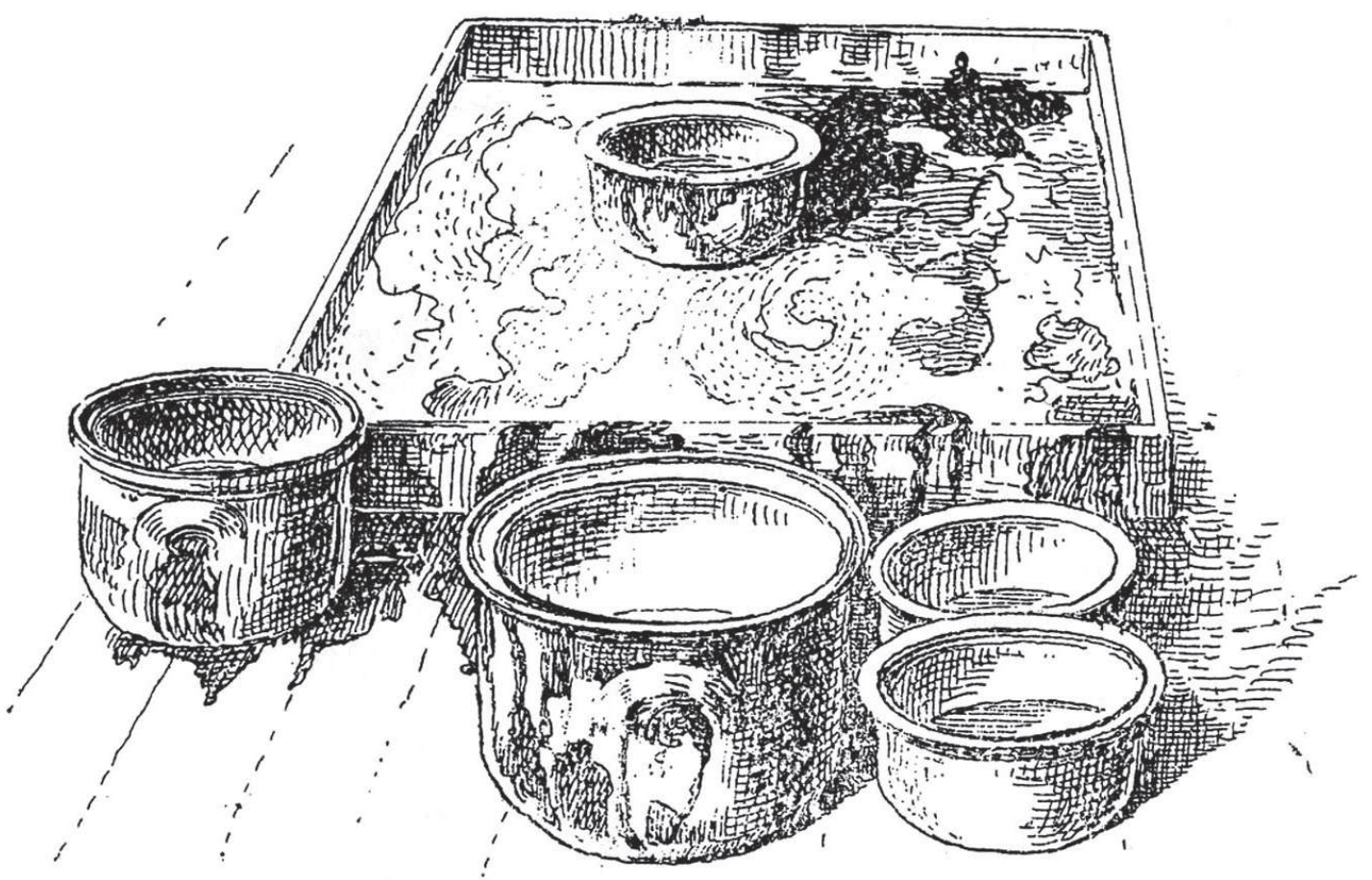

Il. 8. Tradycyjna paleta i ceramiczne naczynia na farby, za: G. Coquiot, Nouveau manuel de peintre décorateur de théâtre, Paris 1927 (faksymil z 1980 r.), s. 120, fig. 32

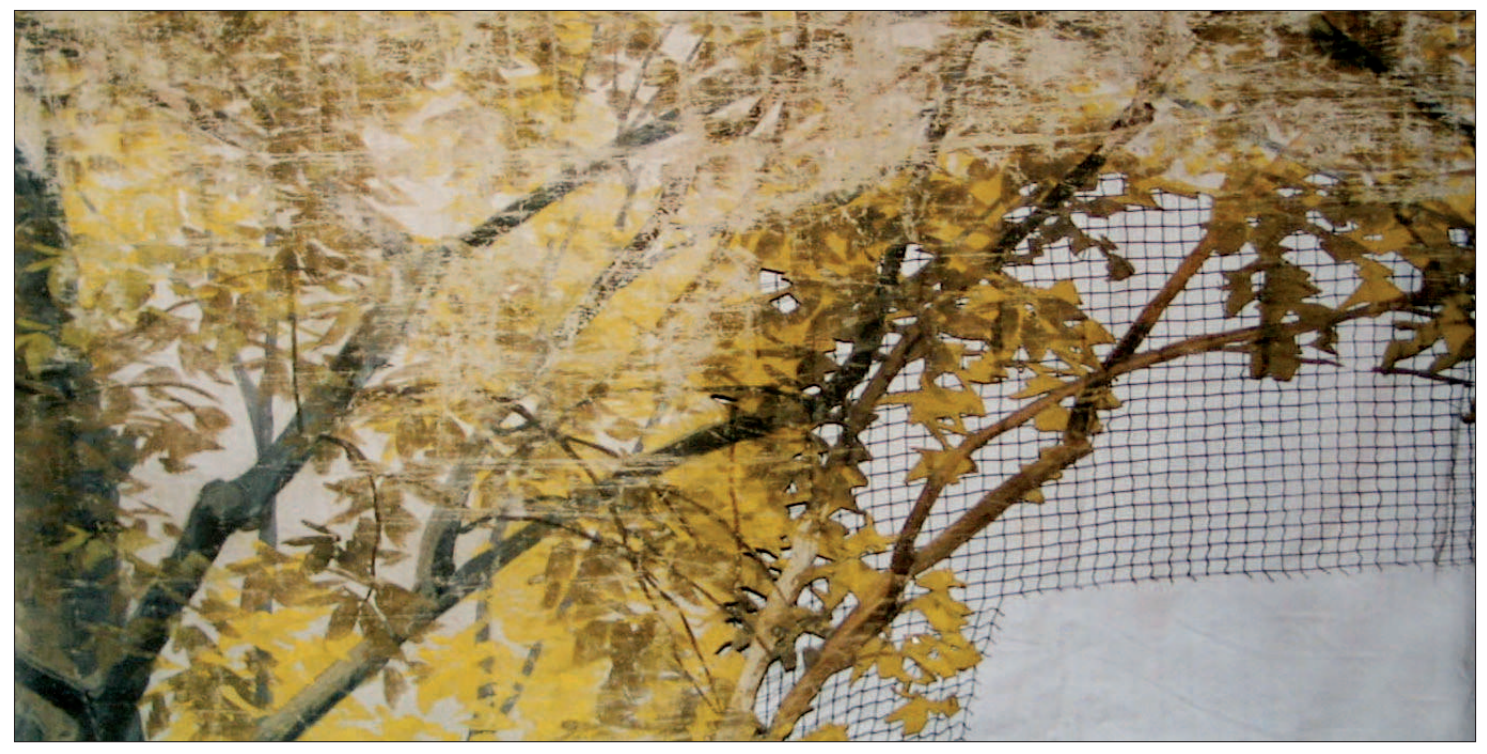

Il. 9. Przykład wzmocnienia partii listowia w suficie siatką tapicerską (fot. W. Kozak) 


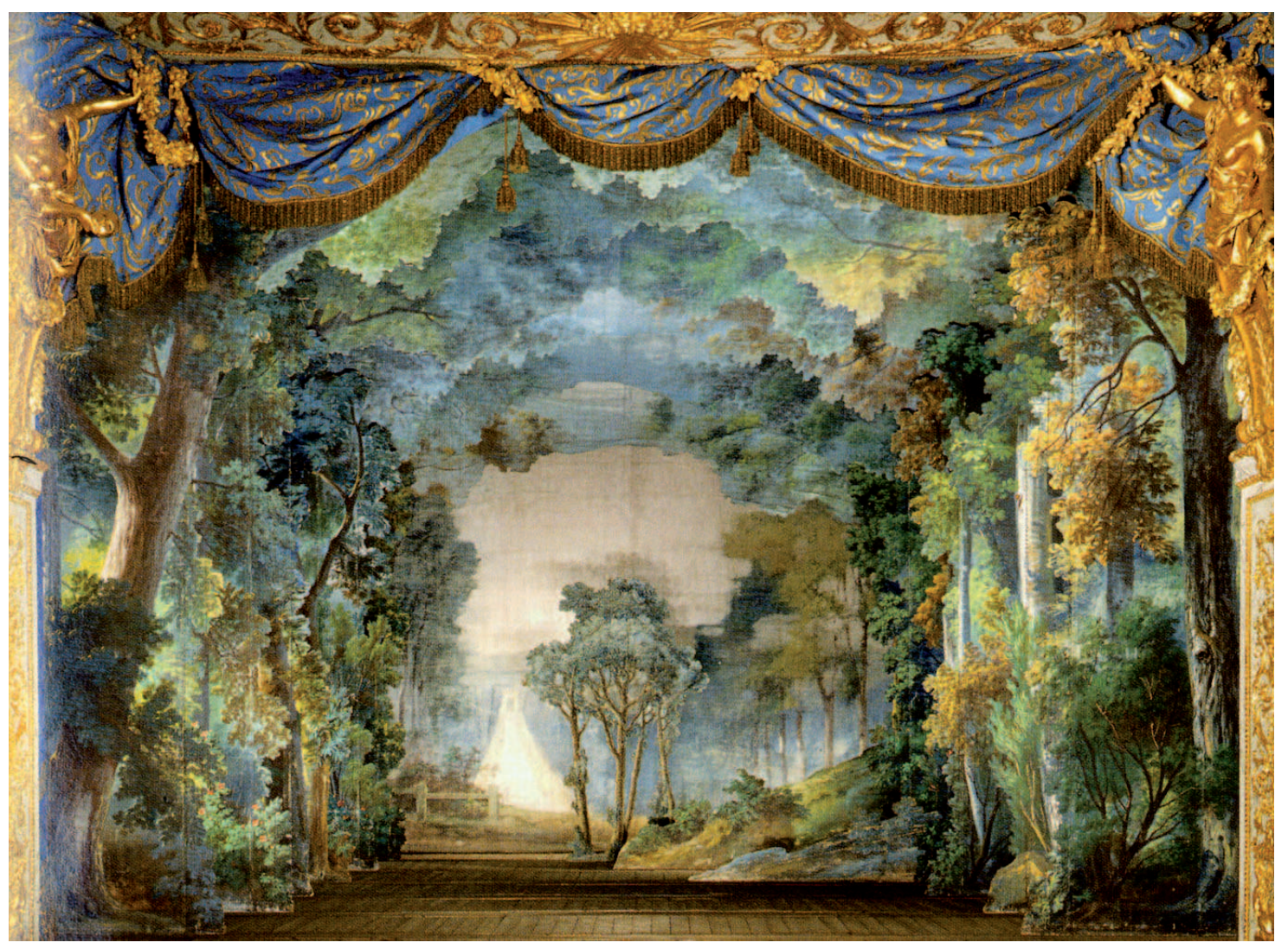

Il. 10. Przykład iluzjonistycznej repertuarowej dekoracji sceny: P.-L. C. Ciceri, 1835 r., Las na scenie Petit Théâtre de la Reine, Wersal, za: „Le Monde de la Musique”, n. 310, juin 2006, s. 47 


\section{Summary}

\section{Illusionistic theatre stage setting as a branch of decorative painting. Technique of the making on example of decorations of French court theatres}

The paper presents material aspects of creating a particular type of decorative painting, that is an illusionistic theatre stage setting. Developed to suite the needs of the stage of Italian type in $17^{\text {th }}$ century, for over two centuries they have made the frame for theatre and opera performances in Europe. The brief outline of the history of illusionistic repertoire decorations is discussed, the catalogue of elements they consisted of as well as technical requirements they had to meet. The principles and subsequent stages of execution of painted stage decorations in $18^{\text {th }}$ and $19^{\text {th }}$ centuries on example of French decorations, with the materials, their application and the tools used being characterised. 